\title{
Repression of Ppargc1a Gene in Liver of Hyperglycemic Rats Induced with High Fat Diet Combined with Streptozotocin
}

\author{
Represión del Gen Ppargc1a en Hígado de Ratas con Hiperglicemia \\ Inducida por Dieta Alta en Grasas Combinada con Estreptozotocina \\ ${ }^{*, * *, * * *}$ Alfonso Hernández; ${ }^{* *}$ Rui Curi \& ${ }^{* * *}$ Luis A. Salazar
}

HERNANDEZ, A.; CURI, R. \& SALAZAR, L. A. Repression of Ppargcla gene in liver of hyperglycemic rats induced with high fat diet combined with streptozotocin. Int. J. Morphol., 30(2):643-650, 2012.

SUMMARY: Type 2 diabetes mellitus implies deregulation of multiple metabolic processes, being the maintenance of glycemia one of the most important. Many genes are involved in the deregulation of this particular process. Therefore, the aim of this study was to evaluate gene expression of genes related to type 2 diabetes mellitus, in the liver and pancreas of rats with hyperglycemia induced by high fat diet along with a low single dose of streptozotocin. Ahsg and Ppargc1a genes were studied in liver, whereas Kcnj11 and Slc2a2 genes were analyzed in pancreas. For this purpose, 210-240 g female rats were fed a high fat diet or a control diet for three weeks. At day 14 , animals fed with high fat diet were injected with a single low dose of streptozotocin $(35 \mathrm{mg} / \mathrm{kg})$ and the control group rats were injected only with the vehicle. Plasmatic glucose, triglycerides and total cholesterol levels were measured at the beginning, day 14 and end of treatment. Body weight was also measured. Once the treatment was complete, rats were appropriately euthanized and then, pancreas and liver were surgically removed and frozen in liquid nitrogen. Total RNA was isolated using TRIzol reagent, treated with DNase I and reversely transcribed to cDNA. Gene expression analysis was performed using SYBR Green - Real time PCR and comparative $\mathrm{Cq}$ method, using three reference genes. Rats fed with high fat diet and treated with streptozotocin showed higher values of plasmatic glucose $(17.09 \pm 0.43$ vs. $5.91 \pm 0.29 \mathrm{mmol} / \mathrm{L}, \mathrm{p}<0.01)$ and a minor expression of Ppargcla versus the control group (2-fold less expressed, $\mathrm{p}<0.05$ ) in liver. We conclude that repression of Ppargcla gene may be an important process in the establishment of chronic hyperglycemia, probably through deregulation of hepatic gluconeogenesis. However, further studies need to be performed in order to clarify the role of Ppargc1a deregulation in liver glucose homeostasis.

KEY WORDS: Gene Expression; Hyperglycemia; Ppargc1a.

\section{INTRODUCTION}

Diabetes Mellitus belongs to a group of metabolic disorders characterized by chronic elevation of blood glucose concentration (hyperglycemia), as a consequence in the failure of insulin secretion, in its action or both (Kahn \& Rosseti, 1998). Type 2 Diabetes Mellitus (T2DM) is the most common form of diabetes. This variant generally does not present autoimmune destruction of pancreatic beta cells, therefore the lack of insulin characteristic of type I diabetes mellitus is not a hallmark of T2DM (ADA, 2007; 2009). Several pathological processes are involved in the onset of this disease, being one of the first in apparition, the reduction of insulin sensitivity in target tissues of this hormone, like skeletal muscle, liver and adipose tissue (Saltiel, 2001). This process leads to an increase of insulin releasing by beta cells in the pancreas, as compensatory mechanism to maintain glucose homeostasis. However, maintenance of this increased insulin production in time, generates a relative deficiency in the releasing of the hormone from pancreatic beta cells, leading to impaired glucose tolerance (Lebovitz $\&$ Banerji, 2004). However, the relative deficiency in insulin secretion is generally a late process in the whole pathogenic scenario, being a characteristic of a frank diabetic state.

Both environmental and genetic factors had been largely associated with the establishment of T2DM (Jenkins \& Campbell, 2004), and jointly contributing to the apparition

" Programa de Doctorado en Ciencias, mención Biología Celular y Molecular Aplicada, Universidad de La Frontera, Temuco, Chile; Programa de Doutorado em Fisiologia Humana, Instituto de Ciências Biomédicas, Universidade de São Paulo, Brasil.

** Department of Physiology and Biophysics, Institute of Biomedical Sciences, University of São Paulo, São Paulo, Brazil.

*** Centro de Biología Molecular y Farmacogenética, Departamento de Ciencias Básicas, Facultad de Medicina, Universidad de La Frontera, Temuco, Chile; Núcleo de Desarrollo Científico - Tecnológico en Biorecursos, Universidad de La Frontera (BIOREN-UFRO), Temuco, Chile.

Este estudio fue financiado mediante Proyecto DIDUFRO DI09-1007. 
of abnormalities in glucose homeostasis. Sedentarism, obesity and diet are the most recognized environmental risk factors (Barroso et al., 2003; Cuevas-Alvarez et al., 2006; Cuevas et al., 2009; Chan et al., 1994; Dowse et al., 1991; Mokdad et al., 2001; Neuhouser et al., 2002; Sohet et al., 2009). On the other hand, the heritable genetic component has also been identified as risk factor of T2DM. From an ethiopatogenic point of view, the high impact of environmental factors and the polygenic character of T2DM are two of the principal differences versus the monogenic character and the relatively poor role of environmental factors in type 1 diabetes mellitus.

Despite the fact that most of studies relating genetic factors and T2DM are based in genetic variations (polymorphisms), other molecular factors can act not only in the establishment of the disease, but also in the maintenance and deterioration of its metabolic and physiologic features. In this way, despite the fact that relatively limited attention has been put at gene regulation level in T2DM, differences in gene expression in some genes related to metabolic pathways could affect not only glucose homeostasis at a global level, but also at organ specific level, probably due to differences in basal gene expression in each singular tissue.

Thus, the aim of this study was to evaluate gene expression of four literature-based candidate genes related to glucose metabolism or diabetes, in pancreas and liver of rats with hyperglycemia induced by high fat diet along with a low single dose of streptozotocin. Alpha-2-HS-glycoprotein (Ahsg) and Peroxisome proliferator-activated receptor gamma, coactivator 1 alpha (Ppargc1a) genes were analyzed liver, whereas Solute carrier family 2 (facilitated glucose transporter), member2 (Slc2a2) and Potassium inwardly rectifying channel, subfamily J, member 11 (Kcnj11) were studied in pancreas.

\section{MATERIAL AND METHOD}

Animals and Experimental design. Hyperglycemic rats were developed based on a previously described protocol (Srinivasan et al., 2005) with modifications. 210-240 g female rats (7-9 weeks of age) obtained from the Central Bioterium of Universidad de Chile, were housed in polypropylene cages at $22 \pm 2{ }^{\circ} \mathrm{C}$ on a $12: 12$ hours light:dark inverted cycle at the Animal House of Universidad de La Frontera. Animals had free access to water and a standard rodent laboratory chow for one week prior to diet manipulation, allowing adaptation of animals to the new environment. After this period, animals were randomly divided in two groups 5 animals each, and fed a high fat diet (HFD; 58\% fat, $13 \%$ protein, $29 \%$ carbohydrate) or a control diet (CD; $35 \%$ fat, $20 \%$ protein, $45 \%$ carbohydrate) for three weeks. At day 14 of dietary manipulation, animals fed with HFD were injected intraperitoneally with a single low dose of streptozotocin $(35 \mathrm{mg} / \mathrm{kg})$, while rats in control group were injected only with the vehicle (citrate buffer, $\mathrm{pH}$ 4.4). Dietary manipulation continued for one more week. Body weight, plasmatic glucose (PGL), triglycerides (PTG) and total cholesterol (PTC) levels were measured at the beginning, day 14, and at the end of treatment (day 22). Rats with fasting plasmatic glucose higher of $16.0 \mathrm{mM}$ were considered hyperglycemic, for purposes of this study. The experiments followed the Guide Principles for the Care and Use of Animals based on the Helsinki Declaration and was approved by our local ethics committee. An overview of experimental design is showed in Figure 1.

Blood collection and biochemical measures. Blood samples $(\sim 100 \mu \mathrm{L})$ were obtained at the beginning of dietary intervention (day 0), prior to STZ injection (day 14) and at the end of treatment (day 21), by puncture of caudal vein. Plasmatic fraction was obtained by centrifugation ( $8 \mathrm{~min}$ at $3000 \mathrm{rpm}$ ) and assayed in triplicate for plasmatic glucose, triglycerides and total cholesterol, using commercial kits based on GOD-PAP, GPO-PAP and CHOD-PAP methods, respectively (Human GmbH, Wiesbaden, Germany), following the manufacturer indications.

Tissue Collection and RNA isolation. Pancreas and liver were obtained from rats after 6 hours fasting. Animals were euthanized using an intracardiac injection of $80 \mathrm{mg} / \mathrm{kg}$ of sodium thiopental. Pancreas and liver were surgically removed, immediately frozen in liquid nitrogen and stored at $-80{ }^{\circ} \mathrm{C}$ until processing. RNA was isolated from $\sim 60 \mathrm{mg}$ of tissue, using TRIzol Reagent (Invitrogen, Carlsbad, CA, USA), with some modifications. Previous to wash step, RNA was precipitated for at least 1 hour at $-20^{\circ} \mathrm{C}$, in order to obtain a greater quantity of RNA. The RNA pellet was dissolved in $60 \mu \mathrm{L}$ of nuclease free water, treated with DNase I (Fermentas, Burlington, Canada) and quantified in NanoDrop ND 1000 UV spectrophotometer (NanoDrop Technologies, Wilmington, DE, USA). RNA integrity was assessed electrophoretically in denaturing TAE agarose gels $(28 \mathrm{~S} / 18 \mathrm{~S}$ rRNA ratio $\geq 2)$ and the purity was verified using OD260/OD280 $\mathrm{nm}$ absorption ratio > 1.8 and OD260/ OD230 $\mathrm{nm}$ absorption ratio $>2.0$.

Reverse transcription and Real-time PCR. For expression analysis of Ahsg and Ppargcla genes in liver, as well as Slc2a2 and Kenj11 in pancreas, DNase treated RNA from corresponding tissue $(1 \mu \mathrm{g})$ was reverse transcribed to cDNA using M-MULV Reverse Transcriptase (Fermentas), 


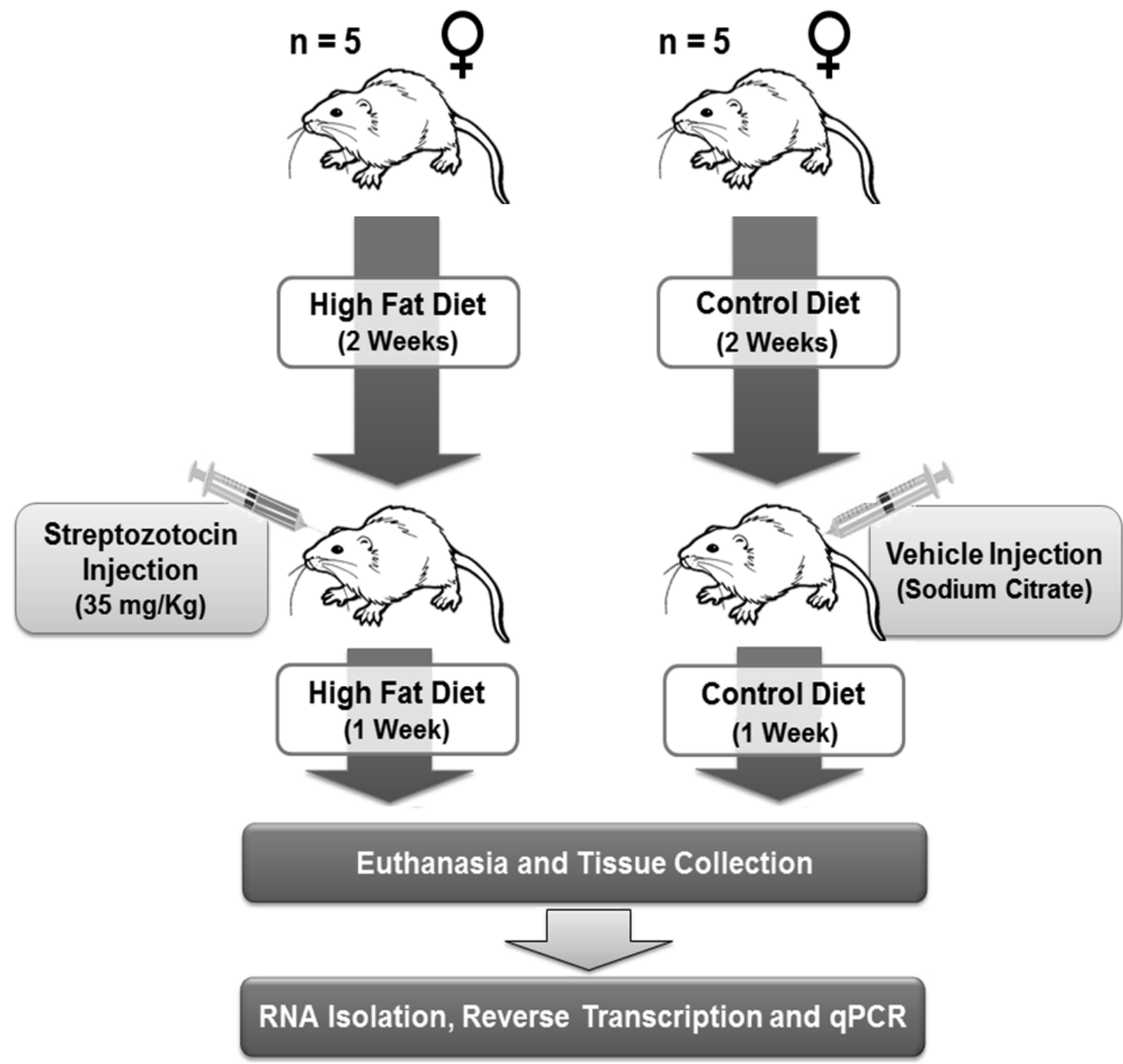

Fig. 1.Overview of experimental design of the study.

following the manufacturer's indications. For real-time PCR, all samples were run in triplicate. PCR Reaction mix (20 $\mu \mathrm{L}$ ) contained $200 \mathrm{ng}$ of cDNA, $100 \mathrm{mM}$ of specific forward and reverse primers and 1x Fast SYBR Green Master Mix (Applied Biosystems, Foster City, California, USA). The primers used are detailed in Table I. All primers were designed using Primer-BLAST tool of the National Center for Biotechnology Information (http://www.ncbi.nlm. nih.gov/tools/primer-blast/). The cycling was performed in a Stratagene Mx3000 QPCR System (Agilent Technologies, Santa Clara, California, USA) with an initial Polymerase activation step of $95^{\circ} \mathrm{C}$ for $10 \mathrm{~min}$, followed by 40 cycles of $95^{\circ} \mathrm{C}$ for $15 \mathrm{~s}, 55^{\circ} \mathrm{C}$ for $30 \mathrm{~s}$, and $72{ }^{\circ} \mathrm{C}$ for $30 \mathrm{~s}$. A dissociation curve was performed at the end of the run, in order to check the quality of primers. Three genes were also run as potential reference genes, analyzing their stabilities with the geNorm tool (Vandesompele et al., 2002). The reaction efficiencies were analyzed using a calibration dilution curve, for each gene (Pfaffl, 2001) and the fold change expression analysis was performed using the comparative $\mathrm{Cq}$ method (2-DDCq).

Statistical analysis. All results are presented as Mean \pm S.E.M. Datasets were submitted to Kolmogorov-Smirnoff normality test. If datasets passed the test, unpaired t test was used to analyzing data between two groups or one-way ANOVA and Tukey's post test, for multiple groups comparisons. If dataset did not shown a Gaussian distribution, Mann-Whitney test was used to compare two groups or Kruskal-Wallis test with Dunns's test as multiple comparison test. A value of $\mathrm{P}<0.05$ was considered statistically significant. 
Table I. Primer sequences of used for gene quantification in Real-time PCR experiments.

\begin{tabular}{|c|c|c|c|}
\hline Gene & $\begin{array}{l}\text { Gene Bank Access } \\
\text { N }^{\infty}\end{array}$ & Primer & Sequence \\
\hline Ribophorin I (RpnI) & NM_013067.1 & $\begin{array}{l}\text { Rpn1F } \\
\text { Rpn1R }\end{array}$ & $\begin{array}{l}\text { CAACCTAGAAGTACGAGAAACC } \\
\text { TGAGTCGGGTATGGATGAAG }\end{array}$ \\
\hline Phosphoglycerate kinase $1(P g k l a)$ & NM_053291.3 & $\begin{array}{l}\text { Pgk1aF } \\
\text { Pgk1aR }\end{array}$ & $\begin{array}{l}\text { ACTGTGGCCTCTGGTATAC } \\
\text { CCCATTCAAATACCCCAACAG }\end{array}$ \\
\hline Ribosomal protein $\mathrm{L} 13 \mathrm{~A}(R p l 13 a)$ & NM_173340.2 & $\begin{array}{l}\text { Rpl13aF } \\
\text { Rpl13aR }\end{array}$ & $\begin{array}{l}\text { GCAAAGATCCATTACCGGAAG } \\
\text { ACAGTCTTTATTGGGTTCACAC }\end{array}$ \\
\hline $\begin{array}{l}\text { Solute carrier family } 2 \text { (facilitated glucose } \\
\text { transporter), member } 2(S l c 2 a 2)\end{array}$ & NM_012879.2 & $\begin{array}{l}\text { Slc } 2 \mathrm{a} 2 \mathrm{~F} \\
\text { Slc } 2 \mathrm{a} 2 \mathrm{R}\end{array}$ & $\begin{array}{l}\text { AGCCCCAGATACCTTTACC } \\
\text { CAGTGCCCCTTAGTCTTTTC }\end{array}$ \\
\hline $\begin{array}{l}\text { Potassium inwardly rectifying channel, } \\
\text { subfamily J, member } 11(\text { Kcnj } 11)\end{array}$ & NM_031358.3 & $\begin{array}{l}\text { Kcnj11F } \\
\text { Kcnj11R }\end{array}$ & $\begin{array}{l}\text { GCCAAGCCCAAGTTTAGC } \\
\text { CCCAGCACTCTACATACCGG }\end{array}$ \\
\hline Alpha-2-HS-glycoprotein $(A h s g)$ & NM_012898.4 & $\begin{array}{l}\text { AhsgF } \\
\text { AhsgR }\end{array}$ & $\begin{array}{l}\text { GGTCCACACTGTCAAAACTG } \\
\text { GCTATCACAAACTCCACGAG }\end{array}$ \\
\hline $\begin{array}{l}\text { Peroxisome proliferator-activated receptor } \\
\text { gamma, coactivator } 1 \text { alpha }(P G C-1)\end{array}$ & NM_031347.1 & $\begin{array}{l}\text { PgclaF } \\
\text { PgclaR }\end{array}$ & $\begin{array}{l}\text { CCCACAGAGAACAGAAACAG } \\
\text { GGGTCAGAGGAAGAGATAAAG }\end{array}$ \\
\hline
\end{tabular}

\section{RESULTS}

Phenotypic characteristics of animals. Characteristics of rats in Control and HFD + STZ groups are shown in Table II. Animals did not show significant differences in body weight, Plasmatic Glucose (PGL), Triglycerides (PTG) nor Total Cholesterol (PTC), between control and HFD + STZ group at the beginning of dietary manipulation. After two weeks of diet administration and previous to administration of STZ or vehicle, animals were weighted and blood samples were taken again. Levels of PTG and PTC showed a significant increase compared with values at beginning of treatment in the HFD + STZ compared to control group while PGL and body weight did not show differences. At the end of the third week of dietary treatment (day 21), rats were evaluated again, showing a significant increment in concentration of PGL ( $p<0.001$ ), so long as the differences in PTG and PTC remain significant ( $p<0.01$ and $p<0.001$ respectively). Body weight did not show differences between Control and HFD + STZ at any time point measured.
Real time PCR reaction quality control. All samples yielded considerable amounts of RNA, over $100 \mu \mathrm{g} / \mathrm{mL}$, whereas $260 / 280 \mathrm{~nm}$ and $260 / 230 \mathrm{~nm}$ indexes were higher to 1.8 and 2.0 respectively, indicating acceptable purity of isolated RNA. The efficiency of real time PCR reactions was near to $100 \%$, for all analyzed genes. The absence of multiple peaks in dissociation curve denoted no primer dimers formation and no non-specific amplification (data not shown).

Gene expression analyses. After verifying the quality of real time PCR reaction, relative expression of mRNA for the interest genes was performed. The analysis of reference genes stability for these three genes showed that in pancreas the most stable genes were Pgk1 and Rpl13a (M-value = 0.09), whereas Rpn1 and Pgk1a were the most stable pair in liver $(\mathrm{M}$-value $=0.11)$. Relative expression level of interest genes were calculated with 2-DDCq formula using the $\mathrm{Cq}$ geometric mean of reference genes above mentioned. Gene

Table II. Characteristics of Control and HFD + STZ rats at the beginning of dietary treatment (day 0), before STZ or Vehicle injection (day 14) and at the end of treatment (day 21).

\begin{tabular}{|c|c|c|c|c|c|c|}
\hline & \multicolumn{2}{|c|}{ Day 0} & \multicolumn{2}{|c|}{ Day 14} & \multicolumn{2}{|c|}{ Day 21} \\
\hline & Control & HFD + STZ & Control & $\mathrm{HFD}+\mathrm{STZ}$ & Control & HFD + STZ \\
\hline Body weight (g) & $249.7 \pm 3.54$ & $237.8 \pm 2.95$ & $259.6 \pm 1.54$ & $255.80 \pm 0.86$ & $271.00 \pm 2.77$ & $272.0 \pm 2.24$ \\
\hline PGL (mmol/L) & $5.30 \pm 0.10$ & $5.33 \pm 0.17$ & $7.28 \pm 0.48$ & $7.65 \pm 0.48$ & $5.91 \pm 0.29$ & $17.09 \pm 0.43 * * *$ \\
\hline PTG (mmol/L) & $4.38 \pm 0.22$ & $4.61 \pm 0.30$ & $4.38 \pm 0.14$ & $5.93 \pm 0.10 * * *$ & $3.76 \pm 0.20$ & $8.71 \pm 1.22 * *$ \\
\hline PTC (mmol/L) & $1.67 \pm 0.03$ & $1.67 \pm 0.08$ & $1.26 \pm 0.11$ & $3.28 \pm 0.18 * * *$ & $1.71 \pm 0.04$ & $3.43 \pm 0.17 * * *$ \\
\hline
\end{tabular}

Values are expressed as Mean \pm S.E.M. The abbreviations denote PGL: Plasmatic Glucose, PGT: Plasmatic Triglycerides, PTC: Plasmatic Total Cholesterol. $* * \mathrm{p}<0.01$ vs. Control group. $* * * \mathrm{p}<0.001$ vs. Control group. $\mathrm{n}=5$ per group. 
expression results for each tissue are shown in Figure 2. Of all studied genes, only Ppargc1a showed a significant reduction in gene expression in liver of hyperglycemic HFD
+ STZ group (2-fold less expressed, $\mathrm{p}<0.05)$, whereas in pancreas neither Slc2a2 nor Kcnj11 showed significant differences.
A

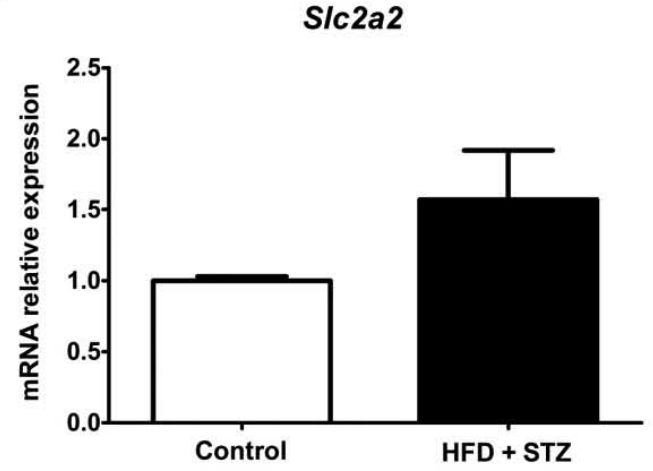

B

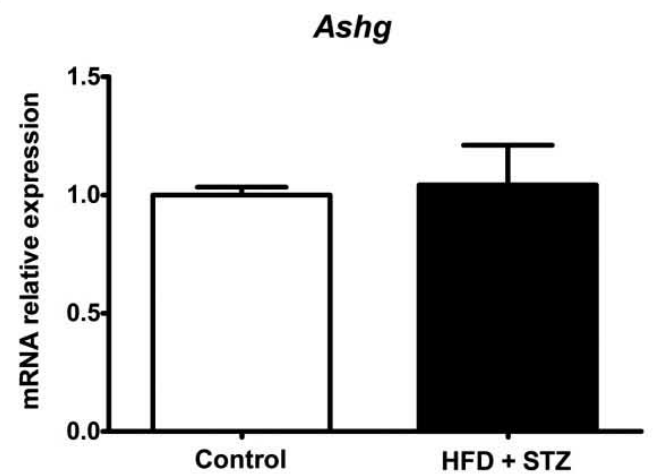

Kcnj11

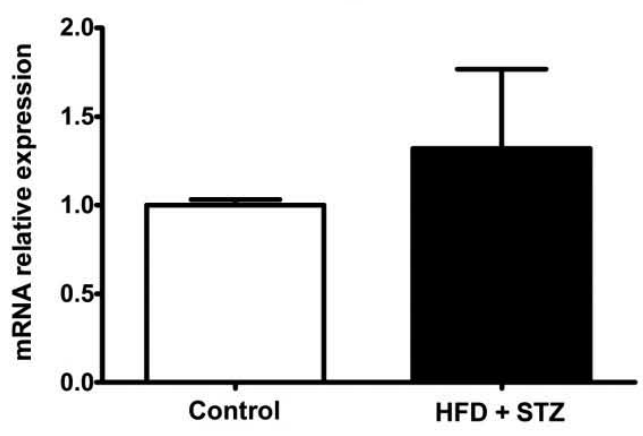

Ppargc1a

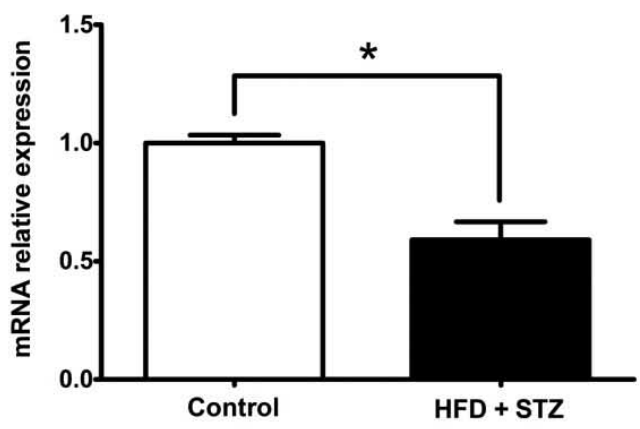

Fig. 2. Relative mRNA expression of the studied genes. A. Genes studied in pancreas. No differences were found in expression levels of Slc2a2 and Kcnj11 genes. B. Genes studied in liver. Only Ppargcla showed differences in gene expression when compared HFD $+\mathrm{STZ}$ vs. Control group. Ashg remains unaltered. $* \mathrm{P}<0.05$.

\section{DISCUSSION}

The principal aim of the present study was to investigate the expression of some diabetes-related genes in pancreas and liver of rats with induced hyperglycemia. First of all, a model of hyperglycemic like type 2 diabetic rats were developed. To achieve this aim, we based our work on previously the described model (Srinivasan et al., 2005), with the differences that female Wistar rats were used instead of male Sprague-Dawley rats and animals were fed with a different diet, but always keeping the character of a high fat diet. This model has two principal advantages. First, the induced metabolic state of animals emulates metabolic features of subjects with advanced type 2 diabetic state. The high fat diet induce an increase of insulin resistance in target tissues, whereas the low dose of STZ induce the decrease of insulin release by the beta pancreas, both characteristics present in advanced type 2 diabetic subjects. Despite the fact that STZ is mostly used for Type 1 diabetes mellitus due to its capacity of induce destruction of beta pancreatic cells causing almost complete lack of insulin when is administrated in high (>65 mg/Kg) or multiple low doses, is important to mention that this drug only generates partial insulin deficiency when is administrated as a single low dose (35- $40 \mathrm{mg} / \mathrm{Kg}$ ). The second advantage is the short time in which the animals achieve a diabetic state, in contrast with 
protocols based only in dietary manipulation. In our study, all animals treated with HFD and STZ generate non-fasting hyperglycemias greater to $16.0 \mathrm{mmol} / \mathrm{L}(290 \mathrm{mg} / \mathrm{dL})$, at the end of treatment, in contrast with rats in control group, which maintain normal glycemia $(5.91 \pm 0.29 \mathrm{mmol} / \mathrm{L}, \mathrm{p}<0.001)$. However, due to technical restrictions, it was impossible to evaluate insulin metabolism of studied animals. Therefore, is not possible to ensure a real development of T2DM in the animals, but only a hyperglycemic state. However, levels of PGL founded in treated animals, suggest a real diabetic state with partial deficiency of insulin, because the glycemias were considerably higher compared with control group but not so high as those found in type 1 diabetic animals.

After characterization of animals and confirmation of the diabetic-like hyperglycemic state, gene expression analysis was performed in liver and pancreas. Selection of reference genes was based on the work of Cai et al. (2007), whom evaluate gene expression of 48 genes in various rat tissues, showing that genes encoding ribosomal proteins and some enzymes related to energetic metabolism processes were the most stables. Therefore, the selected references genes were Pgk1, Rpl13a and Rpn1, for both, liver and pancreas. In pancreas, two genes were studied. Slc2a2 (GLUT2) is the member 2 of solute carrier family 2 (facilitated glucose transporter). In pancreas, it mediates the uptake glucose, process that initiate the glucose-stimulated insulin secretion (Thorens, 2001). Previous studies have associated polymorphisms of Slc2a2 gene with T2DM in humans (Barroso et al., 2003; Kilpelainen et al., 2007). In our study, animals in HFD + STZ animals showed a slight increment in gene expression of Slc2a2, but no statistical difference was found.

The second gene studied in pancreas was the Potassium inwardly rectifying channel, subfamily J, member 11 (Kcnj11). This gene encode for the subunit Kir6.2 of the ATP-sensitive potassium channel (KATP), which is involved in membrane depolarization needed for insulin releasing from pancreatic beta cells (Patch et al., 2007). Polymorphisms of this gene have been found in Type 2 diabetic patients from some ethnic populations (Gong et al., 2011; Yang et al., 2012), turning it as a candidate gene for T2DM. A low expression of this gene could contribute to hyperglycemia, causing lower insulin releasing from beta cells. In our study, no difference was found in gene expression of Kcnj11 gene. However, as in the case of Slc2a2, there is a trend to increased mRNA expression of Kcnj11 in HFD + STZ group. The slight increase in expression levels of these genes could be acting like a compensatory mechanism in response to hyperglycemia present in animals of treated group, in order to increase the insulin releasing from beta pancreatic cells.
On the other hand, Alpha-2-HS-glycoprotein (Ahsg) and Peroxisome proliferators-activated receptor gamma, coactivator 1 alpha (Ppargc1a) genes were analyzed in liver of Control and hyperglycemic rats. Ahsg is a glycoprotein secreted by liver and its principal role is in biomineralization of bone, but also in regulation of insulin signaling. When this function is deregulated, impaired glucose disposal and fatty liver could occur (Goustin \& Abou-Samra, 2011). No differences were detected in gene expression of Ahsg, between Control and DAG + STZ group.

Ppargcla is involved in energetic metabolism, interacting with multiple transcription factors through PPARG. In our study, Ppargc1a showed a significant reduction in gene expression of about $40 \%$ in hyperglycemic animals, when compared with normoglycemic animals. The liver is the principal producer of glucose (through glycogenolysis or gluconeogenesis ways), and Ppargc1a is an important modulator of metabolic activity in this organ, being involved in processes like gluconeogenesis and fatty acid b-oxidation (Liu \& Lin, 2011). When Ppargc1 is induced, it will coactivateFoxO1 and Hnf4a, increasing transcription of gluconeogenic genes such as Pck1 and G6Pase (Rodgers et al., 2008). Thus, a lower expression of Ppargc 1 a will reduce gluconeogenic rate and consequently the release of glucose by the liver. Therefore, the reduction in mRNA levels of Ppargc1a found in HFD + STZ animals could be a compensatory mechanism against hyperglycemia, minimizing the generation and liberation of glucose by liver. In addition, lack of insulin in animals of HFD + STZ group, could alter other co-activators regulated for this hormone involved in gluconeogenic pathway like FoxO1 and Hnf4a, through Akt modulation, possibly affecting the Ppargcla activity as well. In summary, in liver of hyperglycemic rats, decreased gene expression levels of Ppargc1a were found, when compared to the control group. Ppargc1a is an important metabolic regulator in the liver. Decrease of Ppargcla gene expression could act as a compensatory mechanism to hyperglycemia, reducing gluconeogenesis and consequently glucose release from liver. However, further studies need to be performed in order to clarify the role of Ppargc1a deregulation in liver glucose homeostasis, in this animal model.

HERNANDEZ, A.; CURI, R. \& SALAZAR, L. A. Represión del gen Ppargcla en hígado de ratas con hiperglicemia inducida por dieta alta en grasas combinada con estreptozotocina. Int. J. Morphol., 30(2):643-650, 2012.

RESUMEN: La diabetes mellitus tipo 2 implica desregulación de varios procesos metabólicos, siendo la mantención de la glicemia uno de los más importantes. Varios genes están involucrados en este proceso. Así, el objetivo del presente estudio fue evaluar la expresión génica de genes relacionados a 
diabetes mellitus tipo 2 en hígado y páncreas de ratas con hiperglicemia inducida con una dieta alta en grasas junto con una baja dosis de estreptozotocina. Ratas hembra de 210 - $240 \mathrm{~g}$ fueron alimentadas con una dieta alta en grasas o con una dieta control por tres semanas. Al día 14, los animales alimentados con dieta alta en grasas fueron inyectados con una dosis baja de estreptozotocina $(35 \mathrm{mg} / \mathrm{kg})$, mientras las del grupo control fueron inyectadas con el vehículo. El peso corporal y las concentraciones plasmáticas de glucosa, triglicéridos y colesterol total, fueron medidos al inicio, al día 14 y al final del tratamiento. Al finalizar el tratamiento, los animales fueron sacrificados, el hígado y páncreas fueron quirúrgicamente removidos e inmediatamente congelados en nitrógeno liquido. El RNA fue extraído usando el reactivo TRIzol, tratado con DNasa I y posteriormente convertido a cDNA. Los análisis de expresión génica fueron realizados usando SYBR Green - real time PCR y el método del Cq comparativo. En hígado se estudiaron los genes Ahsg y Ppargc1a, mientras que en páncreas se analizaron los genes Slc2a2 y Kcnj11. Las ratas alimentadas con dieta alta en grasas y tratadas con streptozotocina mostraron niveles mayores de glucosa plasmática $(17,09 \pm 0,43$ vs. $5,91 \pm 0,29 \mathrm{mmol} / \mathrm{L}, \mathrm{p}<0,01)$ y una menor expresión hepática de Ppargc1a versus el grupo control (2 veces menor expresión, $\mathrm{p}<0,05)$. En conclusión, la represión del gen Ppargc1a puede ser un importante proceso en el establecimiento de la hiperglicemia crónica, probablemente debido a una desregulación de la gluconeogénesis hepática. Sin embargo, estudios adicionales son necesarios para esclarecer el rol de esta desregulación en la homeostasis hepática de glucosa.

PALABRAS ClaVE: Expresión génica; Hiperglicemia; Ppargc1a.

\section{REFERENCES}

American Diabetes Association (ADA). Diagnosis and classification of diabetes mellitus. Diabetes Care, 30(1): S4247, 2007.

American Diabetes Association (ADA). Diagnosis and classification of diabetes mellitus. Diabetes Care, 32(1): S6267, 2009.

Barroso, I.; Luan, J.; Middelberg, R. P.; Harding, A. H.; Franks, P. W.; Jakes, R.W.; Clayton, D.; Schafer, A. J.; O'Rahilly, S. \& Wareham, N.J. Candidate gene association study in type 2 diabetes indicates a role for genes involved in beta-cell function as well as insulin action. PLoS Biol., 1: E20, 2003.

Cai, J. H.; Deng, S.; Kumpf, S. W.; Lee, P. A.; Zagouras, P.; Ryan, A. \& Gallagher, D. S. Validation of rat reference genes for improved quantitative gene expression analysis using low density arrays. Biotechniques, 42:503-12, 2007.

Cuevas-Alvarez, N. A.; Vela-Otero, Y. \& Carrada-Brav, T. [Identification of risk factors in relatives of type-2 diabetics]. Rev. Med. Inst. Mex. Seguro Soc., 44:313-20, 2006.
Cuevas, A.; Alvarez, V. \& Olivos, C. The emerging obesity problem in Latin America. Expert. Rev. Cardiovasc. Ther., 7:281-8, 2009.

Chan, J. M.; Rimm, E. B.; Colditz, G. A.; Stampfer, M. J. \& Willett, W.C. Obesity, fat distribution, and weight gain as risk factors for clinical diabetes in men. Diabetes Care, 17: 961-9, 1994.

Dowse, G. K.; Zimmet, P. Z.; Gareeboo, H.; George, K.; Alberti, M. M.; Tuomilehto, J.; Finch, C. F.; Chitson, P. \& Tulsidas, H. Abdominal obesity and physical inactivity as risk factors for NIDDM and impaired glucose tolerance in Indian, Creole, and Chinese Mauritians. Diabetes Care, 14:71-282, 1991.

Gong, B.; Yu, J.; Li, H.; Li, W. \& Tong, X. The Effect of KCNJ11 Polymorphism on the Risk of Type 2 Diabetes: A Global MetaAnalysis Based on 49 Case-Control Studies. DNA Cell Biol, 2011 Nov 14. [Epub ahead of print].

Goustin, A. S. \& Abou-Samra, A.B. The "thrifty" gene encoding Ahsg/Fetuin-A meets the insulin receptor: Insights into the mechanism of insulin resistance. Cell Signal, 23:980-90, 2011.

Jenkins, A.B. \& Campbell, L.V. The genetics and pathophysiology of diabetes mellitus type II. J Inherit Metab Dis 27: 331-347, 2004.

Kahn, B. B. \& Rossetti, L. Type 2 diabetes--who is conducting the orchestra? Nat. Genet., 20:223-5, 1998.

Kilpelainen, T. O.; Lakka, T. A.; Laaksonen, D. E.; Laukkanen, O.; Lindstrom, J.; Eriksson, J. G.; Valle, T. T.; Hamalainen, H.; Aunola, S.; Ilanne-Parikka, P.; Keinänen-Kiukaanniemi, S.; Tuomilehto, J.; Uusitupa, M.; Laakso, M. \& Finnish Diabetes Prevention Study Group. Physical activity modifies the effect of SNPs in the SLC2A2 (GLUT2) and ABCC8 (SUR1) genes on the risk of developing type 2 diabetes. Physiol Genomics, 31(2):264-72, 2007.

Lebovitz, H.E. \& Banerji, M.A. Treatment of insulin resistance in diabetes mellitus. Eur. J. Pharmacol., 490:135-46, 2004.

Liu, C. \& Lin, J.D. PGC-1 coactivators in the control of energy metabolism. Acta Biochim. Biophys Sin. (Shanghai), 43:24857, 2011.

Mokdad, A.H.; Bowman, B.A.; Ford, E.S.; Vinicor, F.; Marks, J.S. \& Koplan, J.P. The continuing epidemics of obesity and diabetes in the United States. JAMA, 286:1195-200, 2001.

Neuhouser, M.L.; Miller, D.L.; Kristal, A.R.; Barnett, M.J. \& Cheskin, L.J. Diet and exercise habits of patients with diabetes, dyslipidemia, cardiovascular disease or hypertension. $J$. Am. Coll. Nutr., 21:394-401, 2002.

Patch, A.M.; Flanagan, S.E.; Boustred, C.; Hattersley, A.T. \& Ellard, $\mathrm{S}$. Mutations in the ABCC8 gene encoding the SUR1 subunit of the KATP channel cause transient neonatal diabetes, permanent neonatal diabetes or permanent diabetes diagnosed 
HERNANDEZ, A.; CURI, R. \& SALAZAR, L. A. Repression of Ppargcla gene in liver of hyperglycemic rats induced with high fat diet combined with streptozotocin. Int. J. Morphol., 30(2):643-650, 2012.

outside the neonatal period. Diabetes Obes, Metab,. 9(2):2839, 2007.

Pfaffl, M.W. A new mathematical model for relative quantification in real-time RT-PCR. Nucleic Acids Res., 29: e45, 2001.

Rodgers, J.T.; Lerin, C.; Gerhart-Hines, Z. \& Puigserver, P. Metabolic adaptations through the PGC-1 alpha and SIRT1 pathways. FEBS Lett., 582:46-53, 2008.

Saltiel, A.R. New perspectives into the molecular pathogenesis and treatment of type 2 diabetes. Cell., 104:517-29, 2001.

Sohet, F. M.; Neyrinck, A.M.; Dewulf, E.M.; Bindels, L.B.; Portois, L.; Malaisse, W. J.; Carpentier, Y. A.; Cani, P. D. \& Delzenne, N.M. Lipid peroxidation is not a prerequisite for the development of obesity and diabetes in high-fat-fed mice. $B r$. J. Nutr., 102:462-9, 2009.

Srinivasan, K.; Viswanad, B.; Asrat, L.; Kaul, C.L. \& Ramarao, P. Combination of high-fat diet-fed and low-dose streptozotocintreated rat: a model for type 2 diabetes and pharmacological screening. Pharmacol. Res., 52:313-20, 2005.

Thorens, B. GLUT2 in pancreatic and extra-pancreatic glucodetection. Mol. Membr. Biol., 18:265-73, 2001.

Vandesompele, J.; De Preter, K.; Pattyn, F.; Poppe, B.; Van Roy, N.; De Paepe, A. \& Speleman, F. Accurate normalization of real-time quantitative RT-PCR data by geometric averaging of multiple internal control genes. Genome Biol., 3, RESEARCH0034, 2002.

Yang, L.; Zhou, X.; Luo, Y.; Sun, X.; Tang, Y.; Guo, W.; Han, X. \& Ji, L. Association between KCNJ11 gene polymorphisms and risk of type 2 diabetes mellitus in East Asian populations: a meta-analysis in 42,573 individuals. Mol. Biol. Rep., 39: 64559, 2012.
Correspondence to:

Prof. Dr. Luis Antonio Salazar

Departamento de Ciencias Básicas

Facultad de Medicina

Universidad de La Frontera

Av. Francisco Salazar 01145

Casilla 54-D

Temuco

CHILE

Tel.: +56 45592895

Fax: +56 45592832

E-mail: Isalazar@ufro.cl

Received: 19-01-2012

Accepted: 24-02-2012 